\title{
A PHILIPPINE MODEL FOR INFORMATION SHARING FOR EFFECTIVE REVENUE COLLECTION THROUGH E-GOVERNANCE
}

\author{
Li Jia \\ International College, Krirk University, Thanon Ram Intra, \\ Khwaeng Anusawari, Khet Bang Khen, Krung Thep, Maha Nakhon10220, Thailand
}

\begin{abstract}
Local revenues are the backbone by which local governments anchor the sustenance of their operations, functions and projects within their jurisdiction. Local Government Units (LGU's) in the Philippines depend heavily on local revenue generation- for their development. Although having the Internal Revenue Allotment (IRA) given by the national government through which they support their activities and promote their growth, each local government unit through its treasury office rely on an effective local tax administration and collection system in order to get the best possible resource to serve this purpose. Nevertheless, the problem of local revenue tax collection is a perennial problem and this is traced to many factors that play a part in the inability of the local treasury office to exercise their function to the fullest merit.
\end{abstract}

Optimum tax collection efforts can be enhanced by the local treasury office should it have the ability to synchronize information records which allows the treasury office to check and verify the records taxpayers paying business taxes. Access to this knowledge will give the local treasury the capability to maximize tax collection effectively. And because the local treasury organization like any other government organization is structured to become compatible with new technology development to help it faced with changes in its environment, present day technology in terms of information is now made part of that response. Verification of accuracy of payments through collaborative inter agency efforts is now available. This requires three agencies to collaborate in comparing actual gross sales/receipts from declared gross sales/receipts based on the gathered documents like the books of account, audited financial statements, vat returns and the official receipts as proof of payment of the local business taxes. Three agencies have been mandated to collaborate on this endeavor: the Local City Treasury, the Bureau of Internal Revenue and the Securities and Exchange Commission (SEC). The sharing of vital information related to local revenue collection through the use of technology, especially e-services as part of egovernance has been viewed to enable government to respond positively to problems related to effective public administration.

The paper which will be descriptive in design seeks to assess how e-governance, particular the use of information sharing made accessible through technology in relation to revenue collection. The paper envisions to give credence to new technology in support of a more efficient and effective management of revenue collection for the local treasury.

Keywords: e-Governance, Revenue, Philippine, Model, Information Sharing

\section{INTRODUCTION}

With the advent of advanced technologies from the latter half of the last century all the way to the present century, it is quite necessary for the countries who are seeking to become ahead of the rest of the pack to ensure that they are able to keep abreast of these emerging technologies. These technologies ranged from medical technologies to those with industrial applications such as information technology, both very crucial forms of technologies for any nation to develop. As such, any country's failure to do so would make it quite difficult for them to keep ahead of the rest of the group whether in terms of developing industrial products that are to be sold to other export markets or even of even the simple yet essential need to deliver the basic services to their citizens. Thus, although the ability of nations to implement these technologies in their countries may depend on a variety of factors such as political, social and economic; nevertheless, it is very important that they overcome the challenges from these segments of their national lives in order for them to become fully economically developed. It has been stated by Lyotard that cybernetics has come to dominate economics since after the end of World War II. (1950)

This technological development has many ostensible uses in the political realm. And its most glaring use would be in the information sharing that can be done among governmental agencies within the superstructure of the bureaucracy. It is a well-known fact that the government's 


\section{International Journal of Engineering Applied Sciences and Technology, 2021 \\ Vol. 6, Issue 1, ISSN No. 2455-2143, Pages 1-8 \\ Published Online May 2021 in IJEAST (http://www.ijeast.com)}

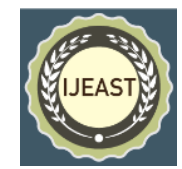

ability to deliver services is hampered by its inability to share information among the many offices within the government. In the Philippines, the previous government tried to set up a government information management system (IMS) through the scandal ridden ZTE broadband deal. Notwithstanding, issues associated with the said government project, it nevertheless highlighted the importance of sharing information among the pertinent government agencies. To date, the Philippine government recognizes the importance of this service, hence, it has been busy setting up an IMS service through a government web portal. This is an exercise in $\mathrm{G} 2 \mathrm{G}$ or government-to-government service. G2G is defined as a government service that "strives to improve the efficiency of delivery when transacting information within itself or with other governments. This allows the government to communicate efficiently by eliminating redundancy and duplication. This also has benefits in terms of crime detection and homeland security. Examples of this quadrant would be intergovernmental cooperation, development of emergency response systems, and linking of law enforcement agencies" ( Vangen and Huxham, 2003).

In the area of revenue collection, the Local City Treasury, the Bureau of Internal Revenue and the Securities and Exchange Commission (SEC) of the Philippine bureaucracy can derive great benefit and thus meet their revenue targets if they could share the information that each agency has in their databases. For example, individuals with registered businesses either with the local city or municipal treasury or with the SEC and even the DTI but fails to report their earnings with the Bureau of Internal Revenue can be traced if ever there is an efficient information management system that grants access to each of these government agencies.

It is crucial therefore for the Philippine government to set up an effective IMS through an effective e-governance mechanism. And should this become a reality, then the government's drive to deliver basic social services will be bolstered through the improved revenue status of the government. In a sense, an improved IMS through egovernance will help bring about an equitable distribution of wealth between the different social classes in our country.

Considering the great importance of a truly cohesive government information management system towards the delivery of public services to the Philippine public, it is really important to overcome the challenges posed by the creation of the said unitary IMS among the country's many e-government portals. The main goal of this research, therefore, is to study how the challenges posed by the creation of said unified IMS for the SEC, BIR and the local treasury offices in the municipalities and cities can be overcome in the Philippines. It is very important, however, to be able to ensure that these challenges be carefully presented first before any possible solutions can be offered towards the creation of a unified Philippine IMS.

\section{THE HISTORY OF IMS AND E- GOVERNANCE}

The changes in the way that the government employs information or computer technology have always rested in the improvements that this particular technology has undergone throughout the years. It can be divided into the following stages.

The 50s has always been known as introduction or the pioneer stage. During this initial stage, computers were primarily employed as ways through which scientific calculations were performed as well as in performing huge yet routinely administrative tasks.

The $60 \mathrm{~s}$, on the other hand, was able to bring about the creation and subsequent development of large mainframe computers, as well as large centralised computer systems, wherein the main processors that were large enough to fill an entire room were held at regional computing centres. And they typically are able to communicate with so called 'dumb' terminals that are without any processing power.

For its part, the roaring 70s was a period that was characterized by the development of applications. And its emphasis was the creation of different varieties of programs. As such, three types of information technologists became important, namely, programmers, systems designers and developers. In addition, this period also saw the spreading of terminals across departments like wildfire. This came about because of the steep drop in the prices of computers that finally commenced in the 80 s, eventually, these computers which were huge and bulky were replaced by personal computers with their own processing power and storage capabilities. In addition, the development of database technologies also came about. This occurrence, in turn, provided a structured store of data, thus, it was possible to eliminate duplication and to reflect the nature of the data, instead of simply the particular needs of certain applications that processed them.

When the mid-1980s finally set in, simple yet effective applications of information technology became commonplace in almost all businesses in the manufacturing and service sectors. This was primarily seen in the automation of many of the work activities in these sectors. Hence, this brought about the integration of the prevailing technological trend at the time as embodied by information technology. On the downside, however, with the introduction of automation in the aforementioned sectors, some jobs that were formerly held by human workers became obsolete and they were subsequently 'let go' from their work. On the positive side 


\section{International Journal of Engineering Applied Sciences and Technology, 2021 \\ Vol. 6, Issue 1, ISSN No. 2455-2143, Pages 1-8 \\ Published Online May 2021 in IJEAST (http://www.ijeast.com)}

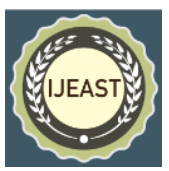

though, this translated to lower overhead cost inasmuch as the repetitive tasks that were formerly performed by a number of human workers were now performed by a simple application of an IT program.

As the 1990s made its presence, personal computers were developed by a number of companies from the Silicon Valley as well as in their Asian and European counterparts, thus, increasing their numbers several folds and making their presence felt in many offices and homes. Moreover, these PCs as they came to be known were now linked in networks within the many work sections of a single organization as well as among different organizations, both private/corporate as well as their public/governmental counterparts. This all important development underscored the formal beginning of information sharing among workmates in an organization or among different organizations themselves.

Loh and Venkatraman (1994) stated that "private and public telecommunications networks played an especially important part in these developments, bringing changes to the availability and flexibility of information technology. These changes mean that the possibilities that information technology offers in the 1990s are considerably greater than merely providing a faster, larger, automated filing system." This meant that all types of organisations started to take on relatively new tasks that would never have been conceivable had this technology did not come about. To date, information technology has become an intrinsic part of all companies in the private sector that to dispose of them would be to the detriment of the survival of the business. As such, it can be said that information technology is now an extremely crucial part of the company's business strategy. Loh and Venkatraman go on to say that, "it is now a truism that information technology has transcended its established administrative support functions and has moved towards playing a more central role in business operations."

When these developments in computer and information technology came about, these resulted in numerous improvement in the delivery of efficient government service in the highly industrialized countries in the West where these developments initially came about. In particular, the United States and the United Kingdom were at the forefront among these nations. It came not as a surprise, therefore, that they experienced unprecedented economic growth at the tail end of the last century and at the beginning of the present century because of the improved state of their manufacturing industries. More importantly, their citizens were at the receiving end much improved services. If in the past, they would have to fall in long lines and wait days for basic government services, all these became things of the past as government agencies shared information due to the 'computerization of government services in the abovementioned two countries'.

\section{III. DERIVING OSTENSIBLE BENEFITS FROM INFORMATION SHARING AND E- GOVERNANCE}

Just how much better would government services become as a result of IMS and e-governance? Information technology has been heralded "as a new fairy godmother for government" (Margetts, 1999). As such, various politicians of different political colors have tried to associate themselves with the perceived benefits of IT and using it for IMS and egovernance. For one, they heralded it as the 'new age of government' that will inevitably put the final nail in the coffin of all governmental abuse and misappropriation of public funds. The United States had an unwavering champion of the benefits of this new technology in the person of former vice president Al Gore, who first coined the phrase 'information superhighway' in 1977. He announced that 'With computers and telecommunications, we need not do things as we have in the past. We can design a customer-driven electronic government that operates in ways that, 10 years ago, the most visionary planner could not have imagined' (NPR, 1993:1212).

It is the dream of most politicians to fashion a country that can be interconnected in a wired network of computers and modems. Information can connect all students in all classrooms and libraries, patients from the most medically advanced hospital to the least technologically adept clinic in a 'national information infrastructure' by the year 2000. The politicians in Great Britain also took note of the developments in their distant cousins from the other side Atlantic. Then Deputy prime Minister, Michael Heseltine, stated that "information technology would bring the nervous system of a new order to education" (Guardian, 14 November 1995).

A great number of scholars and public policy experts have pored through data and materials in their quest to study the relationship between economically successful nations and their ability to gather, transfer and use information. Kraemer and Decrick (2002) sufficiently studied the relationship between government investment in IT and the economic growth in 12 Asia-Pacific countries. They found out that over a seven-year period, there is a significant positive correlation between growth in IT investment and growth in both GDP and productivity. Moreover, they were able to find out that "countries with higher growth rates in IT investment achieved consistently higher growth rates of GDP and productivity. Their results support the contentions that IT results or is crucial to economic development.

The challenge that remains, however, is the cost of the said information sharing through e-governance. Laying down the technological infrastructure is not going to cost peanuts. On the contrary, it will cost quite a hefty sum. For a 


\section{International Journal of Engineering Applied Sciences and Technology, 2021 \\ Vol. 6, Issue 1, ISSN No. 2455-2143, Pages 1-8 \\ Published Online May 2021 in IJEAST (http://www.ijeast.com)}

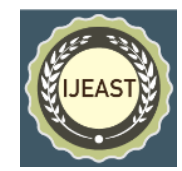

third world country like the Philippines, this might prove to be an insurmountable challenge. Then again, should it desire to join the first rank of nations with economic superiority, it has to take advantage of this technology. Kraemer and Dedrick (1994) admonishes countries to invest heavily in IT. Their study has shown that " Thailand, Korea, India and Taiwan have shown the fastest growth in IT investment, and they have ranked among the leaders in productivity growth. The only countries in which productivity growth appears to lag relative to growth in IT investment are Australia/New Zealand and the Philippines."

\section{A PHILIPPINE MODEL FOR IMS AND E- GOVERNANCE LED DEVELOPMENT}

So what should the Philippine government do in light of these proven correlational value between huge investments in information technology as specifically manifested in a national information management system and e-governance?

The answer is quite obvious. If the country is to be leap frog in terms of economic development then it has to follow suit with its more economically progressive counterparts. The previous administration of Gloria Macapagal Arroyo, has sought to improve the country's information systems with some investments and private equity partnerships with foreign and local companies in IT infrastructure. This is manifested in the botched NBN-ZTE scandal that was meant to link all the country's municipal and city halls in one broadband network. Through the years, it has been trying to increase its bandwidth. However, the real issue remains, that is, its ability to use the information it has in its government databases and share it among the government agencies to be able to create public policy that will ensure the success of government programs. There is a need then to ensure that the end users of these information managements systems (IMS), that is, government bureaucrats are able to share information with each other in order to draft policies that will truly be beneficial to the country. Their failure to do so would mean that the cost of doing business in the country will remain high given that businessmen, both domestic and foreign, will have to be burdened by a lot of round around and red tape before they can even start doing their business. Imagine the benefit of a singular IMS in processing applications such as securities or business licenses. Time will surely be significantly diminished if there is sharing of IMS among government agencies instead of having to go to different agencies for a singular business or securities application.

This of course will require a great commitment on the part of the government to create a truly unified IMS database. A real IT revolution has to create great benefits in terms of its impact on the socioeconomic conditions of the people, especially in the countryside. The IT revolution has to reach out to the general masses, a possibility that can be made all the more possible in a unified IMS database.

Many countries all over the world have come to realize the importance have seen the need for e-government given their ability to communicate with the people and the improved ability to transfer information from both sides of the communication divide between the people and the government. As such, the need for electronic portals through which the government will be able to provide their services to the people. Conversely, the people will have a better access to information relating to their government's programs. Without doubt, the Philippines has recognized this phenomenon, thus, it has created a great number of e-government portals. The only problem then is the ability of these different government portals to share their information with each other. At present, any citizen with enough technological know-how to browse through the internet may go through the Philippine government's web portal. However, the question for this particular research remains this, how can the local treasury office, Bureau of Internal Revenue (BIR) and Securities and Exchange Commission (SEC) share information to be able to get the right amount of taxes let us say from one particular individual.

Look at it this way, all of these offices contain within their databases the information that would be able to determine how much monetary transactions an individual makes within a year. And should these government agencies share this information among themselves, then the government would be able to exact the proper tax responsibility that one owes to the government. Therefore, this fact highlights the need for these three agencies to share information among each other.

In light of the fact that a government is serviceoriented, it must be stated that all service activities depend generally on the amount of information that is available as well as on its accuracy and timely delivery. It has to be stated that information technology systems do not only support the really important functions of the government like protecting the safety of the public, public transportation, as well as public works projects. Moreover, information technology is also very important to all function of the government relative to human resources, financial activities and capital management endeavors. One of the government performance project model of government performance and management capacity included IT as one of the pillars of management capacity. It is said to be equal in importance to human resource, finance, and capital management.

Considering that technology is so pervasive that it permeates all activities relating to the government's ability to perform its functions, from applications relating to the internet all the way to applications that provide services to the citizens as well as systems that process the payrolls of the employees of the government employees. In the years leading to the turn of the new millennium, the world's overall dependence on this type of technology became the source of the fear of many 


\section{International Journal of Engineering Applied Sciences and Technology, 2021 \\ Vol. 6, Issue 1, ISSN No. 2455-2143, Pages 1-8 \\ Published Online May 2021 in IJEAST (http://www.ijeast.com)}

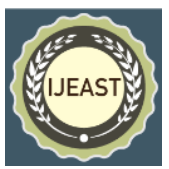

countries that stores and sends information via computers through what came to be known as the Y2K crisis. Many people from scholars to the ordinary layman became aware of the threat that computers the world over from the simple personal computers to the more complicated large mainframe computers could cease to function normally because of their inability to process the information as the millennium/century/year changed from 1999 to 2000. Mindful of this threat, all the necessary precautions were done to ensure that the feared event did not take place. The looming crisis riveted the attention of elected officials everywhere on the need to prepare legacy systems for the turn of the century, prompting state and local governments to accelerate information technology decisions and adjust budget priorities. It awakened governing bodies to the centrality of IT in government performance and management capacity.

The story of IT management in U.S. government began as a story of operating practitioners adapting successful private sector technologies for use in their respective public sector functions (Ingraham, 2007).

\section{THE SEC, BIR AND THE LOCAL TREASURY}

According to its website, this agency seeks "to strengthen the corporate and capital market infrastructure of the Philippines, and to maintain a regulatory system, based on international best standards and practices, that promotes the interests of investors in a free, fair and competitive business environment" (http://www.sec.gov.ph/). For its part, the Bureau of Internal Revenue is "is committed to collect taxes for nation-building through excellent, efficient and transparent service, just and fair enforcement of tax laws, uplifting the life of every Filipino" (http://www.bir.gov.ph/about/about.htm). While the local treasury of municipalities and cities across the country, are tasked to collect fees and payments of local businesses in their territorial jurisdiction. As such, every entrepreneur has to go through any or all of these agencies if he desires to start a business in the country. Keeping this in mind, within its information databases rest a crucial element that would help to raise the revenue collection of the country.

As of now, all the governments all over the world has realized the importance to be able to share the information that they possess in their databases to be able to improve the delivery of government services. The same can be said about internal revenue collection also. Sharing the information among these revenue collection agency as well as other agencies such as the Bureau of Customs and the Department of Trade and Industry will invariably raise the country's revenue collection. Inasmuch as information technology at present times is already a very important facet to government operations, the need for a Philippine model of information sharing through e-governance should be conceived and actualized by the Philippine government.

\section{BENEFITS FROM IMS THROUGH E- GOVERNANCE}

The present economic turmoil that has engulfed the world has been borne by the failures of the western governments, that is, the United States and its European allies to keep abreast with the changing financial situation until it was too late. The United States government for its part waited in the sidelines and acted too late even as it saw many of its people defaulting on their home mortgages as they were losing their jobs to their counterparts overseas. They have failed to pay heed to the warning that has been echoed both by the sociologist Alvin Toffler and the theorist Jean Francois Lyotard that in the new world order, information is the key. And nowhere and at no time is this truer than in the highly technologically advanced western societies. Their technological superiority should have allowed them the opportunity to get the information they needed to forestall and foresee any disaster that was developing. The new century is not dubbed as the information age for nothing. In this day and age, only the countries who are able to sufficiently handle the demands of information gathering and transfer will succeed. China has to keep this fact in mind if it is to avert any similar scenario that its western counterparts are currently experiencing.

As such, it must be noted that the great increase of economic power that many Asian countries as such as China has been experiencing in recent years has a correlational effect on its ability to improve its technological infrastructure, from communication satellites to its military might. However, in this postmodern world that Lyotard has characterized as the information age, the success of any country rests on its ability to be able to transfer information to countless users. And this is more importantly seen in a highly advanced informational technology infrastructure.

In the case of the Philippines, however, several roadblocks have prevented the creation of a unified information management system that would share the many information databases that are kept by different government agencies. As a result of which, these agencies are unable to create a comprehensive IMS that would be able to make the delivery of basic services faster and more efficient. The importance of such a mechanism has been underscored by Pardo et al. when they said "The central role of information integration in realizing the benefits of digital government and the breadth and depth of the challenges facing governments as they seek to use and share information serve as the catalysts for this symposium issue. In a simple conceptualization, information integration allows managers to work at the same time, with the same information drawn from multiple disparate sources. In a more complex form, it has the potential to support the transformation of organizational structures and communication channels between and among multiple 


\section{International Journal of Engineering Applied Sciences and Technology, 2021 \\ Vol. 6, Issue 1, ISSN No. 2455-2143, Pages 1-8 \\ Published Online May 2021 in IJEAST (http://www.ijeast.com)}

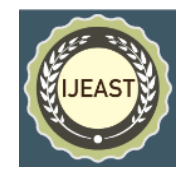

agencies working in different locations. It requires radical technical and organizational process and behavior changes for the individuals and organizations involved (Pardo, Gil-Garcia, \& Burke, 2006).

The basic thrust of this paper is then is to be able to inculcate on the minds of the public policy makers in the Philippines to be able to start institutionalizing the creation of an information sharing structure that would be made possible through the setting up of an e-governance infrastructure. Moreover, it is the desire of this researcher to be able to tell the public policy makers in the country to expedite the setting up of the technological infrastructure to make this possible. The government has to heed the call of Daly and Cui (2003) who said that this technology is extremely crucial given that "the rise of e-commerce has opened an entirely new front in which the Chinese economy must catch up. The Internet has become an important tool in supply chain management, with everything from vendor catalogs to shipment and order tracking to scheduling handled electronically (Daly and Cui 2003).

More importantly, it is crucial to start setting up the technology for e-governance by asking the three aforementioned government agencies to be able to share their information databases with one another. Should they be able to do so, then the correlational effect of improving productivity, namely, the government's ability to provide services will surely come into play.

\section{THE PHILIPPINE MODEL}

What would be able Philippine model that would work for the prospected information sharing for these three government agencies?

It has been noted that one serious challenge would have to be the cost of the said project as stated previously in another section of this paper. Another would have to be the technological ability of the Philippines to bring this into reality. Furthermore, the physical as well as territorial challenge of making this a reality also has to be considered especially in light of the fact that the Philippines is an archipelago. sectors.

The solution to these problems would lie in many

For the first challenge, the government can undertake a public-private equity sharing or a build operate transfer scheme similar to the one that it has implemented in many of its other major infrastructure projects such as the MRT and LRT Line 2.

For the second challenge, the government can take lessons from the experiences of the other countries by employing the heuristic model. Considering the great importance of a truly cohesive government information management system towards the delivery of public services to the Philippine public, it is really important to overcome the challenges posed by the creation of the said unitary IMS among the Philippine government's three concerned Egovernment portals. It is very important, however, to be able to ensure that these challenges be carefully presented first before any possible solutions can be offered towards the creation of a unified Philippine IMS since it would help improve the government's ability to collect revenues from its people.

Although at present the issue of an integrated information management system has been carefully studied in many countries by numerous academics, nonetheless, it has not been studied exhaustively by academics and researchers in the Philippine context. Moreover, it has yet to be evaluated in terms of the causes that are preventing its successful integration as well as the possible solutions to these causes. Thus, most if not all of the information relating to this issue is derived primarily from news people. Although most of these news people are well intentioned, nonetheless, many of them employ novice methods of research. As such, they fail to ferret out the important aspects of the issue. People seeking to study this issue only had a few materials available to them to examine their areas of interest. This is all the more true on the issue of an integrated IMS considering that this is a fairly recent phenomenon that has captured the imagination of both the public and the academe. Thus, any researcher will certainly encounter a scarcity of scholarly sources on the subject matter. It is for this reason that this research is such a significant undertaking in light of the fact that it will address this dearth in the literature. Secondly and more importantly, this study is significant also because this will help shed light on the reasons why the Philippines has yet to have to an integrated information management system. The failure of most government agencies to take the initiative to create this integrated IMS will surely be glossed over during the research. Also, it will help the readers to understand the importance one such integrated IMS. Likewise if this research is read carefully by policy makers, they will see the need to push the administrators and stakeholders of government agencies to learn from the experiences of other countries who have become more efficient in the delivery of their people's basic needs. At present though, the researcher is convinced that these government agencies are already aware of possible solutions to the problem. However, for reasons that escape the researcher, they fail to put the needed measures into action. Hence, this is a crucial study to serve as a reminder and wake up call for these people. Most importantly, this research will elucidate that although an integrated IMS is indeed difficult to actually realize, it is nevertheless achievable by intently addressing its causes. In doing so, proposed solutions will be offered to these causes. The experience of other countries who have successfully curbed this issue will be of help in this regard. 


\section{International Journal of Engineering Applied Sciences and Technology, 2021 \\ Vol. 6, Issue 1, ISSN No. 2455-2143, Pages 1-8 \\ Published Online May 2021 in IJEAST (http://www.ijeast.com)}

Therefore, in order to fully bridge the digital divide to help bring about a truly efficient practical technological applications, three crucial elements have to be borne in mind. These are the following: entrepreneurship, government policies encouraging and supporting equity and ground level programs with local community participation.

As of now, a great percentage of the Philippine population belongs to the traditionally backward communities. It is important that computer education should be particularly focused on these groups. Considering that a sizeable portion of the Philippine bureaucracy have not undergone any formal training on IT and even computer applications, there is a need to train the pertinent staff of the three said agencies where these information sharing through e-governance will be implemented. The success or failure of the program's goal $/ \mathrm{s}$ rests on this one single fact. Only if highly competent people who are able to implement this project will be trained will this program become a success.

Also, there might be a need to fully develop the needed IT software in some regional languages and through pictures and icons to enable the not so computer adept to acquire information is one approach.

More importantly, there is a need to establish networks to interlink the far flung municipalities across the nation. Especially those that are located across the seas and far flung areas. Each municipal center might have multiple institutional identities, it might serve as a virtual community center, bank, medical resource, government counter, matrimonial bureau, public library and educational resource center all at once.

The direct and immediate benefits of use of IT in government are improvements in service quality, efficiency and government-people relationships by providing quick, easy and transparent access to information. There is an urgent need to target basic needs, such as primary education, basic health services, water and sanitation requirements, particularly in rural and backward areas. The new ICT applications and content relevant to the demand in rural areas can drastically improve the delivery of information related services to people in general and the agriculture extension services and the provision of health and social services in rural areas in particular.

\section{CONCLUSION}

The Philippine policymakers has to take into account the fact that it has to implement the project by looking at the bigger picture, that is, it might cost substantial investment to make this information sharing scheme through e-governance between the three agencies possible; however, in the long run, the benefits will far outweigh the costs once the revenue collection of the government increases as a result of a more truthful assessment of the Philippine public's ability to pay their taxes is assessed with the right and good quality information.
Moreover, the formation of partnerships between local bodies, the local administration and NGOs appears to hold the key. The development of applications, such as an online system for community banking, will contribute to the economic sustainability of the operations. It will also go a long way to humanize and sensitize the Philippine information revolution.

\section{REFERENCES}

1. Luis F. Luna-Reyes, J. Ramon Gil-Garcia, Cinthia Betiny Cruz. Collaborative digital government in Mexico: Some lessons from federal Web-based interorganizational information integration initiatives. Government Information Quarterly 24 (2007) 808826

2. Donna Evans, David C. Yen. E-Government: Evolving relationship of citizens and government, domestic, and international development. Government Information Quarterly 23 (2006) 207235.

3. J. Ramo'n Gil-Garci'a, Theresa A. Pardo, Egovernment success factors: Mapping practical tools to theoretical foundations. Government Information Quarterly 22 (2005) 187-216.

4. Shawn P. Daly, Lindsay X. Cui. E-logistics in China: basic problems, manageable concerns and intractable solutions. Industrial Marketing Management 32 (2003) 235- 242

5. Dawes, S. S., \& Pardo, T. A. (2002). Building collaborative digital government systems. Systematic constraints and effective practices. In W. J. McIver \& A. K. Elmagarmid (Eds.), Advances in digital government. Technology, human factors, and policy (pp. 259-273). Norwell, MA: Kluwer Academic Publishers

6. Ortega, F., Gonzalez-Barahona, J. M., \& Robles, G. (2008). On the inequality of contributions to Wikipedia. In Proceedings of the 41st Annual Hawaii International Conference on System Sciences (HICSS 2008). Waikoloa, HI.

7. Palisade. (n.d.). Retrieved April 05, 2014, from http://www.palisade.com/

8. Parasie, S., \& Dagiral, E. (2012). Data-driven journalism and the public good: "Computer-assistedreporters" and "programmer-journalists" in Chicago. New Media \& Society, 15, 853-871.

9. Rawls, J. (1993). Political liberalism. New York, NY: Columbia Univ. Press.

10. Sæbø, Ø., Rose, J., \& Skiftenes Flak, L. (2008). The shape of eParticipation: Characterizing an emerging research area. Governme 
11. The Australian Historic Newspapers Trove. (n.d.). Retrieved October 26, 2013, from http://trove.nla.gov.au/

12. Wimmer, M. A., Scholl, J., Gro" nlund, A., \& Gro"nlund, A(2007). Proceedings of the Electronic goverment: $6^{\text {th }}$ International Conference, EGOV 2007 (p. 450). September 3-7. Regensburg, Germany: Springer Science \&Business Media.

13. Wright, M. M. (2005). Finding a place in cyberspace: Black women, technology, and identity. Frontiers, 26, 48-59.

14. Yildiz, M. (2007). E-government research: Reviewing the literature, limitations, and ways forward. Government Information Quarterly, 24, 646-665.

15. Your Priorities. (n.d.). Retrieved April 05, 2014, from https://yrpri.org/home/world 